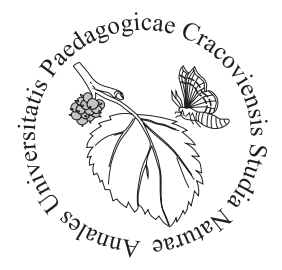

Angelika Kliszcz , Joanna Puła

University of Agriculture in Krakow, Department of Agroecology and Plant Production, Mickiewicza 21 Ave, 30-120 Kraków, Poland; ‘angelika.kliszcz@student.urk.edu.pl

\title{
Assessment of earthworms activity based on eaten biomass from selected catch crops
}

Introduction

In order to preserve the homeostasis of the soil environment and increase its fertility, the presence and activity of soil mesofauna, especially earthworms, is an essential factor (family Lumbricidae Rafinesque-Schmaltz, 1815). By feeding on plant and animal residues, as well as microorganisms, earthworms form resources of soil organic matter that are permanently associated with the soil's mineral phase (Wu et al., 2018). A network of corridors formed by individual ecological groups of earthworms contributes to the regulation of water-air relations in soil. According to Bouché (1972), three main ecological groups of earthworms can be distinguished in the soil profile: anecic, endogeic and epigeic. For agroecosystems, the first two play a key role. Anecic species (e.g. Lumbricus terrestris L.) live deep in the soil profile (up to several meters) and form corridors with a further to the vertical slope, which communicate earthworms with a substantial food source, i.e. with plant debris left on the ground (e.g. in the form of mulch). However, their basic component of the diet is the mineral part of the soil, which they eat while drilling corridors. Their activity contributes to better water infiltration and the creation of 'fertile' corridors on the walls of which reside bacteria in the organic matrix left by earthworms (coprolytes, body's excrement). They are also weed seed vectors, which enriches the soil seed bank located at deeper levels. Endogeic species from the second ecological group intensify their activity in the arable soil layer, near plant roots (up to $30 \mathrm{~cm}$ deep) and create galleries with a horizontal slope, contributing to the formation of proper humus reservoir in the plant rhizosphere. Also these species are vectors of microorganisms and seeds in the inhabited area (Clause et al., 2017). They are also species that prefer a large proportion of organic remains in addition to the mineral part of the soil. 
The presence and activity of earthworms in the cultivated field can be limited by the intensification of cultivation treatments (Briones, Schmidt, 2017) and the use of herbicides (Kostecka, 1999; Pelosi et al., 2014). The introduction of plant biomass into the field, for example in the form of catch crops, is an additional source of food and can contribute to an increase in the earthworm population. The presence and activity of earthworms increases the fertility of the soil habitat, which creates favourable conditions for the growth and development of crop plants.

Each animal selects, per se, the most rich in content - optimal food that it needs. For earthworms these are: plant and animal debris, living and dead soil organisms (bacteria, fungi, protozoa, algae, nematodes, amoebas) (Curry, Schmidt, 2007), as well as excrements of various living organisms, minerals, ions in the free state in soil solution. Penetrating the soil profiles of almost every square meter of soil on the Earth's surface, earthworms, when drilling corridors and taking food, decide what and in what quantity will be collected and processed by them. However, this fascinating mechanism of food preferences in earthworms is not yet fully understood. The first work on the trophic behaviourism of earthworms appeared in ancient times (Li et al., 2010), and the deliberations were continued with considerable publicity by Charles Darwin, who devoted the last 30 years of his life to studying the life and functions of earthworms in the process of forming soil organic matter. When food is consumed by the earthworm, a decisive role is played by a part of the neural ganglion, which is stimulated by chemical receptors located in the prostomium (above-mouth lobe) and from receptors on the entire body surface of the earthworm. These receptors provide the earthworm with information about the environment in which it is currently located. Generally, the trophic mechanism in the earthworm consists in collecting through the mouth, then swallowed pieces pass through pharynx, the esophagus and enter the crop, in which they are temporarily kept and mixed with a concentrated suspension of calcium carbonate produced by calciferous gland's secretory cells localised at the end of the esophagus. Next, the food goes to a heavily muscled stomach (gizzard), then passes into the intestine, from where it is excreted in the form of casts through the anus. Despite the absorption of nutrients by the body of the earthworm, droppings are a valuable and rich component of soil matrix and remain compact for a long time. It is interesting that despite high concentrations of phenolic compounds in plant material and their adverse effect on the precipitation of proteins in living organisms, plant biomass remains the main substrate for earthworms. The research of Liebeke et al. (2015) shows that drillodefensins (surface active lipophilic ions 259.1013 Da, which $\mathrm{m} / z$ are consistent with a molecular formula of $\mathrm{C}_{12} \mathrm{H}_{19} \mathrm{O}_{4} \mathrm{~S}^{-}$) are produced in the earthworm body, which are produced in the foregut section of earthworms and help them digest phenolic-rich residues plant. 
One way to assess the trophic activity of earthworms is to quantify their ability to eat food per unit of time. The aim of the study was to evaluate the possibility of processing food (mixed with soil catch crop residues from white mustard (Sinapis alba L.), buckwheat (Fagopyrum esculentum Moench) and tansy phacelia (Phacelia tanacetifolia Benth.) and crop biomass which was spring triticale $(\times$ Triticosecale Wittm. ex A.Camus) by earthworms of the species Lumbricus terrestris L. regard to control object (soil from the field). An interesting further question concerned examining whether any of the plants can be preferred (more willingly taken) by earthworms, thus may supposedly contribute to an increase in their numbers in the field.

\section{Material and methods}

\section{Study material}

The model organism in the experiment were individuals of Lumbricus terrestris, a species from the anecic group, which are known for drawing plant organic matter from the soil surface into their corridors reaching 2 meters deep into the soil (Bogdanowicz et al., 2004), and that while burrowing corridors, they also pass a significant amount of the mineral part of the soil through the gastrointestinal tract (Rouse, 2016).

\section{Assessment of food intake by earthworms}

The assessment of food intake by earthworms was performed in laboratory conditions in experiment with Petri dishes. Earthworms were purchased from a commercial supplier (Ekagro) and kept for 4 hours in the dark $\left(15^{\circ} \mathrm{C}\right)$ in a container with wet tissue paper to empty their digestive tract. Then $1 \mathrm{~L}$. terrestris individual (average weight $4.99 \mathrm{~g}$ ) was placed in one Petri dish $(\varnothing 11 \mathrm{~cm})$, in seven replications, and was incubated in a vegetation chamber (darkness, $18^{\circ} \mathrm{C}$ ) in a completely randomised system. The food material ( $20 \mathrm{~g}$ per Petri dish) was airdried fragmented plant biomass $(7 \% \mathrm{w} / \mathrm{w})$ sieved through a $\varnothing 1 \mathrm{~mm}$ sieve and mixed with soil sterilised at $105^{\circ} \mathrm{C}$ which was sieved through a $\emptyset 2 \mathrm{~mm}$ sieve and brought to field humidity (approx. 35\%). The amount of food eaten by each individual was assessed after $12 \mathrm{~h}, 24 \mathrm{~h}$ and $63 \mathrm{~h}$ with an accuracy of $0.0001 \mathrm{~g}$.

Before measuring each dish with food (7 replicates), the earthworm and wet paper were removed, then excrements and coprolites left on the Petri dish during the animal's activity were wiped with paper, and then the together with food was weighed (later subtract the weight of each dish). All results were corrected for values resulting from natural weight loss of food recorded simultaneously for objects without earthworms. 
Statistical analysis

The results regarding the food intake of earthworms were analysed based on ANOVA with repeatable measurements and a grouping factor (food material) or one-way ANOVA ( $\mathrm{C}$ and $\mathrm{N}$ content; ratio of food intake) and subjected to the Tukey HSD test at $\alpha=0.05$.

\section{Results and discussion}

The dynamics and amount of food intake at 12-hour intervals (Fig. $1 \mathrm{~A}-\mathrm{B}$ ) indicates that this geophages species prefer soil as food. However, among the plant biomass supplements, earthworms most often took white mustard (Sinapis alba L.) ( $0.80 \mathrm{~g}$ after the first 12 hours). These food tendencies of earthworms remained until the end of the experiment, and this is all the more surprising because plants of the Brassicaceae Burnett family have thioglycosides of volatile mustard oils in their tissues, which after being subjected to mechanical grinding and under the influence of the enzyme myrosinase, may decompose in white mustard to toxic and irritating soft tissues p-hydroxybenzyl isothiocyanate (Sawicka, Kotiuk, 2007).

Tab. 1. Nitrogen (N) and carbon (C) content in the biomass of analysed plants and in soil

\begin{tabular}{lccc}
\hline Object & $\mathrm{N}[\%]$ & $\mathrm{C}[\%]$ & $\mathrm{C} / \mathrm{N}$ ratio \\
\hline Phacelia tanacetifolia Benth. & $1.81 \pm 0.018 \mathrm{~b}$ & $40.04 \pm 0.004 \mathrm{c}$ & 22.1 \\
Sinapis alba L. & $1.94 \pm 0.032 \mathrm{a}$ & $42.18 \pm 0.170 \mathrm{a}$ & 21.8 \\
Fagopyrum esculentum Moench & $1.57 \pm 0.040 \mathrm{c}$ & $40.27 \pm 0.083 \mathrm{c}$ & 25.7 \\
×Triticosecale Wittm. ex A.Camus & $1.83 \pm 0.021 \mathrm{~b}$ & $41.68 \pm 0.077 \mathrm{~b}$ & 22.8 \\
(spring) & $0.08 \pm 0.003 \mathrm{~d}$ & $0.64 \pm 0.023 \mathrm{~d}$ & 8.54 \\
soil (control) &
\end{tabular}

mean values $\pm S D, n=3$; different letters next to values indicate different homogenous group, HSD Tukey test, $\alpha=0.05$

The third measurement, after more than 3-times a further exposure $\left(63^{\text {rd }}\right.$ hour of the experiment), revealed even greater discrepancies in soil uptake (15.13 g) and soil with the addition of plant biomass ( $1.37 \mathrm{~g}$ on average). At $63^{\text {rd }}$ hour of the study, there was a disruption in the metabolism of earthworms in the form of a secreted white substance in a facility with tansy phacelia (Phacelia tanacetifolia Benth.), which resulted in a lower uptake of eaten food than assessed after 24 hours and this also became the basis for the termination of the experiment.

The dynamics of food intake showed acceleration of consumption for some objects and exposure times, and sometimes earthworms took food constantly (Fig. 1). For example, tansy phacelia are characterised by increased intake dynam- 

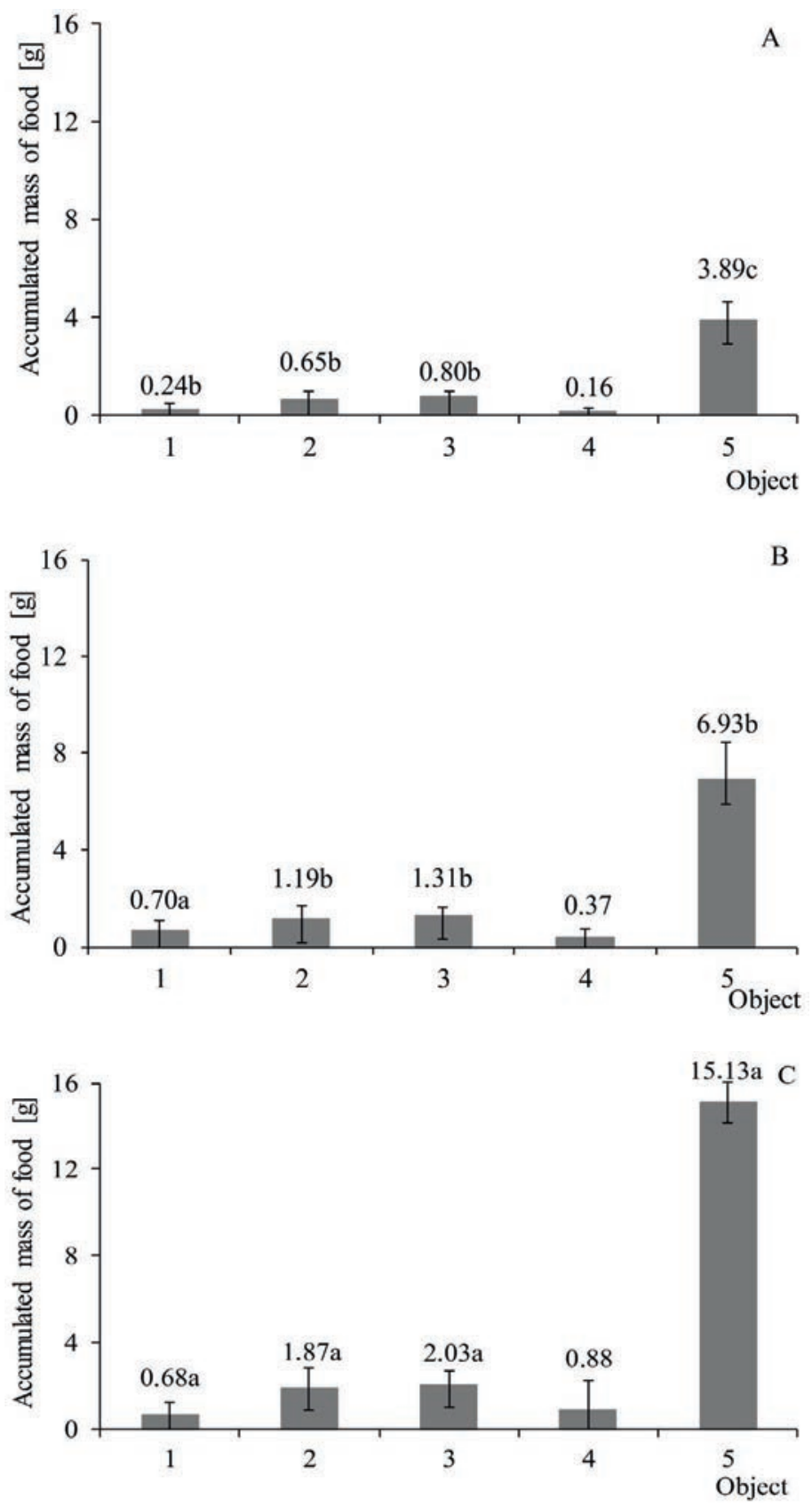

Fig. 1. Accumulated mass of food eaten by earthworms Lumbricus terrestris L. (A) after 12 hours, (B) after 24 hours, (C) after 63 hours, $(\mathrm{n}=7)$; different letters next to values indicate different homogenous group inside the one object with a time, HSD Tukey test, $\alpha=0.05$; ${ }^{*}$ for $\times$ Triticosecale $\mathrm{p}$-value $=$ 0.360579; object: 1 - Phacelia tanacetifolia Benth., 2 - Fagopyrum esculentum Moench, 3 - Sinapis alba L., 4 - ×Triticosecale Wittm. ex A.Camus, 5 - soil (control) 
ics between 12 and 24 hours of exposure (190\%), just as triticale between 12 and 24 hours (131\%) and 24-63 hours (138\%). White mustard and buckwheat were taken changeless at both time intervals, with more dynamic (though less quantitatively) uptake of buckwheat (83 and 57\%, respectively) and balanced uptake dynamics for white mustard (57 and 55\%, respectively).

Earthworms, as a biological component that increases soil fertility, are particularly valuable in soil and plant cultivation systems, in which it is not possible to increase this fertility by introducing fertilisers and soil conditioners into the system. This is the case in the organic farming system. Non-use of plant protection products and a larger amount of organic matter going back to the field mean that this system has a greater biodiversity, quantity and biomass of earthworms, although the plough tillage is a decisive factor (Bilalis et al., 2009; Munro et al., 2002). In this context, the conducted research may allow the identification of species-specific trophic behaviour of earthworms (food processing capability, intake dynamics) and estimation of the impact of the earthworm population and their trophic behaviourism on the positive (or negative) effect on the growth and development of plants in organic crops.

It should be noted, that the practice of leaving plant residues in the form of mulch on the soil surface has been known in agriculture for a long time and it is used now, especially in organic farming. Although, according to Jodaugiene et al. (2010) the largest amount and biomass of earthworms is concentrated under grass mulches (av. 185 number per $\mathrm{m}^{-2}$ and $42.5 \mathrm{~g} \times \mathrm{m}^{2}$ respectively), the selection of plants was not accidental in this experiment, because tansy phacelia, white mustard and buckwheat belongs to the plants widely used in organic farming, at least because of their phytosanitary properties in relation to commercial crops (Majchrzak et al., 2005).

Plants used in the food material used in the experiment were subjected to biochemical analysis for nitrogen and carbon content (Tab. 1). The data show that white mustard, which the earthworms took the most, also had the highest $\mathrm{C} / \mathrm{N}$ ratio (25.7), while in spring triticale, whose intake was the most dynamic during the whole experiment, this ratio was at the level of 22.8.

A good estimator of the quantitative and qualitative food intake by earthworms is the ratio of the weight of food taken (per day) to the average body weight of the earthworm - F24/AWE (Tab. 2). Based on the obtained results, it was observed that the activity of earthworms increased more than threefold in objects with an addition of catch crop biomass in relation to spring triticale. 
Tab. 2. Comparison of the ratio of food intake from various plant species during the 24 hours to the average body weight of the earthworm (Lumbricus terrestris L.); AWE - average weight of the earthworm, AWFT - average weight of food taken in total after 24 hours, F24/AWE - ratio of food intake per 24 hours to the average weight of the earthworm

\begin{tabular}{lccc}
\hline Plant species & AWE [g] & AWFT [g] & F24/AWE \\
\hline Phacelia tanacetifolia Benth. & $5.00 \pm 1.022$ & $0.70 \pm 0.365$ & $0.14 \mathrm{~b}$ \\
Fagopyrum esculentum Moench & $4.93 \pm 1.555$ & $1.19 \pm 0.545$ & $0.24 \mathrm{~b}$ \\
Sinapis alba L. & $4.86 \pm 1.614$ & $1.31 \pm 0.348$ & $0.27 \mathrm{~b}$ \\
$\times$ Triticosecale Wittm. ex A.Camus (spring) & $5.21 \pm 1.197$ & $0.37 \pm 0.340$ & $0.07 \mathrm{~b}$ \\
soil (control) & $4.93 \pm 0.965$ & $6.93 \pm 1.982$ & $1.41 \mathrm{a}$ \\
mean value for plants & $5.00 \pm 1.375$ & $0.89 \pm 0.557$ & 0.18 \\
\hline
\end{tabular}

average means $\pm S D, n=7$; different letters next to values indicate different homogenous group, HSD Tukey test, $\alpha=0.05$

It is estimated that in maize cultivation in temperate climate, 100 individuals of L. terrestris species per $1 \mathrm{~m}^{2}$ process on average $840 \mathrm{~kg}$ of litter per year (Bohlen et al., 1997). In this experiment, a new indicator, the decomposition rate, was used, which tells how many kilograms of food used (mixture of soil and plant biomass) pass through the digestive tract of 100 individuals per year, in this case L. terrestris (Fig. 2). It can be useful in estimating the contribution of individual soil fauna species to the transformation processes of the organic substance of the agroecosystem in a time interval. Estimation through this indicator gives the opportunity to assess the impact of a particular species, taking into account its synecology (population ecology), living in a given ecosystem and the ability to compare the effectiveness of organisms (including earthworms) in various crops. However, it is advisable to collect the organisms before calculating the decomposition index in order to estimate their real number in the studied area.

The most effective crops in terms of processing of plant biomass by earthworms of the species L. terrestris (assessment based on the calculated decomposition rate) would be white mustard and buckwheat (the highest values in figure 2). On the other hand, in quantitative terms, the biomass of cereal plants represented by spring triticale was almost three times less processed compared to other tested plants.

To correctly assess the impact of the earthworm population on the plant biomass cycle in the agroecosystem, it should be taken into account that earthworms as burrowers require more space for their activities, so that the spatial stress factor does not inhibit them from activity. Therefore, field experiments in the mesocosm system are the most commonly used in this type of research. On the other hand, laboratory experiments are short and reflect the food preferences of individuals quite well. 


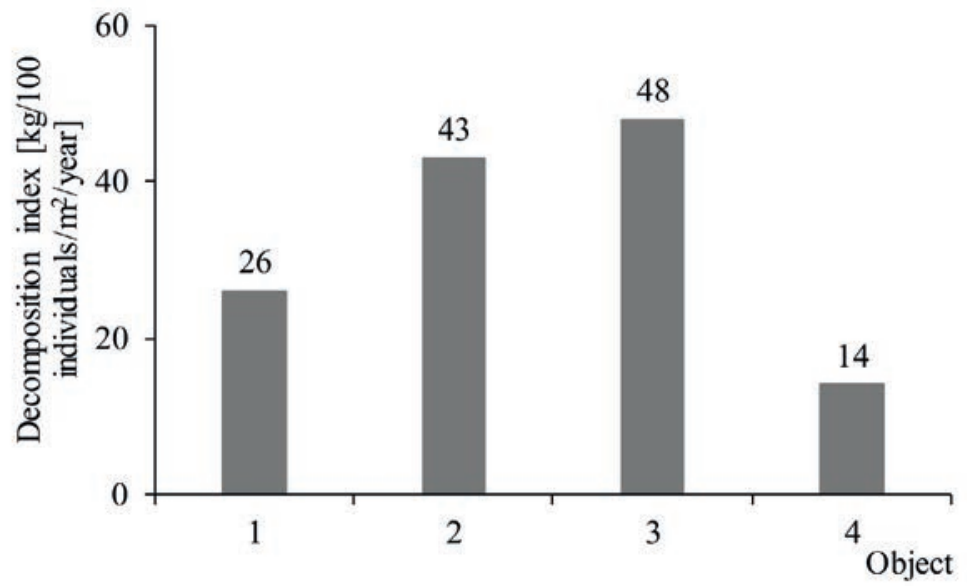

Fig. 2. Estimated average mass of food eaten by 100 individuals (Lumbricus terrestris L.) based on the results of a laboratory experiment; 1 - Phacelia tanacetifolia Benth., 2 - Fagopyrum esculentum Moench, 3 - Sinapis alba L., 4 - ×Triticosecale Wittm. ex A.Camus

Conclusion

The conducted analyses show that Lumbricus terrestris shows food preferences in relation to crop biomass, as the eurybiont of many habitats in temperate climate. During the 63 hour experiment, soil $(15.1 \mathrm{~g})$ constituted the most food material collected by earthworms, and among the plant components - the one with the addition of Sinapis alba $(2.03 \mathrm{~g})$. However, the object with the addition of $\times$ Triticosecale spring was characterised by the highest consumption dynamics (the average of 135\%). Food material with the addition of tansy phacelia was taken up the fastest in the first 24 hours (190\%), but later it fell sharply until changes in animal metabolism were recorded.

The ratio of food intake per day to the average body weight of one earthworm exceeded the unity threshold (1.41) only in the case of the soil object. In other cases (non-cereal plants) it oscillated around 0.22 and only in triticale reached three times lower (0.07). The most favorable decomposition rate was recorded for white mustard, whose estimated amount of food eaten by earthworms (with a local population of 100 individuals) would be approximately $48 \mathrm{~kg} / \mathrm{m}^{2} /$ year in the field. The assessment of the possibility of food processing by earthworms, as well as the determination of their population in the field, can be very helpful in the organic farming system, where the biological component plays a key role in increasing soil fertility.

Acknowledgment

The research was financed from the funds of the Ministry of Science and Higher Education as a part of a subsidy (BM No. 2119).

Conflict of interest

The authors declare no conflict of interest related to this article. 


\section{References}

Bilalis, D., Sidiras, N., Vavoulidou, E., Konstantas, A. (2009). Earthworm populations as affected by crop practices on clay loam soil in a Mediterranean climate. Acta Agriculturae Scandinavica Section B Soil and Plant Science, 59(5), 440-446. DOI: 10.1080/09064710802342327

Bogdanowicz, W., Chudzicka, E., Pilipiuk, I., Skibińska, E. (2004). Fauna Polski. Charakterystyka i wykaz gatunków. Tom 1. Annelida. Warszawa: Wydawnictwo Instytutu i Muzeum Zoologii PAN, p. 1-11. [In Polish]

Bohlen, P.J., Parmelee, R.W., McCartney, D.A., Ewards, C.A. (1997). Earthworm effects on carbon and nitrogen dynamics of surface litter in corn agroecosystems. Ecological Application, 7, 1341-1349.

Bouché, M.B. (1972). Lombriciens de France. Paris: Ecologie et Syste'matique, Institut National de la Recherche Agronomique. [In French]

Briones, M.J.I., Ostle, N.J., Piearce, T.G. (2008). Stable isotopes reveal that the calciferous gland of earthworms is a CO2-fixing organ. Soil Biology \& Biochemistry, 40, 554-557. DOI:10.1016/j.soilbio.2007.09.012

Briones, M.J.I., Schmidt, O. (2017). Conventional tillage decreases the abundance and biomass of earthworms and alters their community structure in a global meta-analysis. Global Change Biology, 23, 4396-4419. DOI: $10.1111 / \mathrm{gcb} .13744$.

Clause, J., Forey, E., Eisenhauer, N., Seal, C.E., Soudey, A., Colville, L., Barot, S. (2017). Seed selection by earthworms: chemical seed properties matter more than morphological traits. Plant Soil, 413, 97-110. DOI: $10.1007 / \mathrm{s} 11104-016-3085-9$

Curry, J.P., Schmidt, O. (2007). The feeding ecology of earthworms. Pedobiologia, 50, 463-477. DOI: 10.1016/j.pedobi.2006.09.001

Jodaugiene, D., Pupaliene, R., Sinkeviciene, A., Marcinkevisciene, A., Zebrauskaite, K., Baltaduonyte, M., Cepuliene, R. (2010). The influence of organic mulches on soil biological properties. Zemdirbyste, 97(2), 33-40.

Kostecka, J. (1999). Wpływ wybranych insektycydów na dżdżownice. Zeszyty Problemowe Postępów Nauk Rolniczych, 467, 603-607.[In Polish]

Li, K., Li, P. Li, H. (2010) Earthworms helping economy, improving ecology and protecting health. International Journal of Global Environmental Issues, 10(3), 354-365. DOI: 10.1504/IJGENVI.2010.037276

Liebeke, M., Strittmatter, N., Fearn, S., Morgan, A.J., Kille, P., Fuchser, J., Wallis, D., Palchykov, V., Robertson, J., Lahive, E., Spurgeon, DJ., McPhail, D., Takáts, Z., Bundy, J.G. (2015). Unique metabolites protect earthworms against plant polyphenols. Nature Communications, 6, 7869. DOI: 10.1038/ ncomms 8869 .

Majchrzak, B., Waleryś, Z., Ciska, E. (2005). Phytosanitary value of cruciferous plants as pre-crops of cereals I. Glucosinolate content in stems and roots of mature plants of Brassicaceae family. Oilseed Crops, 26, 199-209.[In Polish]

Munro, T.L., Cook, H.F., Lee, H.C. (2002). Sustainability indicators used to compare properties of organic and conventionally managed topsoils. Biological Agriculture \& Horticulture, 20(3), 201-214. DOI: 10.1080/01448765.2002.9754965

Pelosi, C., Barot, S., Capowiez, Y., Hedde, M., Vandenbulcke, F. (2014). Pesticides and earthworms. A review. Agronomy for Sustainable Development, 34, 199-228. DOI: 10.1007/s13593-013-0151-z

Rouse, G.W. (2016). Phylum Annelida: the segmented (and some unsegmented) worms. In: Brusca, R.C., Moore, W., Schuster, S. (eds.), Invertebrates, Third Edition. Sunderland: Sinauer Associates, p. 540569.

Sawicka, B., Kotiuk, E. (2007). Gorczyce jako rośliny wielofunkcyjne. Acta Scientiarum Polonorum seria Agricultura, 6(2), 17-27. [In Polish] 
Wu, Y., Shaaban, M., Peng, Q., Zhou, A., Hu, R. (2018). Impacts of earthworm activity on the fate of straw carbon in soil: a microcosm experiment. Environmental Science and Pollution Research, 25, 11054-11062. DOI: 10.1007/s11356-018-1397-4

Abstract

The trophic activity of soil mesofauna, especially earthworms (the Lumbricidae family), is a key element in increasing the fertility of agroecosystems. The food strategies that earthworms use as part of the trophic networks in soil, and especially their food preferences, are still unknown. Much is known about what is the food substrate of earthworms, but the food preferences of individual species, as well as the possibilities and dynamics of food processing are not fully understood. The aim of the experiment was to observe the amount and dynamics of food uptake by the earthworms of the species Lumbricus terrestris L., which is a common species of soil Oligochaeta in agricultural areas, as well as to propose a new decomposition rate measuring the strength of the earthworm population and its contribution to the mechanism of processing plant organic matter.

Key words: agroecosystem, Lumbricidae, cover crops

Received: [2019.05.07]

Accepted: [2019.10.11]

\section{Ocena aktywności dżdżownic na podstawie pobrania biomasy z wybranych międzyplonów \\ Streszczenie}

Aktywność troficzna mezofauny glebowej, zwłaszcza dżdżownic (rodzina Lumbricidae), stanowi kluczowy element w podnoszeniu żyzności agroekosystemów. Strategie pokarmowe jakie stosują dżdżownice będące częścią sieci troficznych w glebie, a zwłaszcza ich preferencje pokarmowe są wciąż niepoznane. Wiele wiadomo na temat tego co jest substratem pokarmowym dżdżownic, to jednak nie do końca poznano preferencje pokarmowe poszczególnych gatunków, a także możliwości i dynamikę przerobienia pokarmu. Celem eksperymentu było zaobserwowanie ilości oraz dynamiki poboru pokarmu przez dżdżownice z gatunku Lumbricus terrestris L., będącej powszechnie występującym gatunkiem skąposzczetów glebowych na obszarach użytkowanych rolniczo, a także zaproponowanie nowego wskaźnika dekompozycji, mierzącego siłę i wkład populacji dżdżownic w proces przerabiania roślinnej materii organicznej.

Słowa kluczowe: agroecosystem, Lumbricidae, międzyplony

\section{Information on the authors}

Angelika Kliszcz https://orcid.org/0000-0002-1270-4414

She is focusing on enhancing the understanding of the influence of different factors on soil structure and fertility. Particularly, she is investigating the interaction of plants with the physical, chemical, and biological properties of the soil. She is also interested in earthworm ecology and mesofauna function in agroecosystems.

Joanna Puła https://orcid.org/0000-0002-3672-5690

Her research is connected with agrotechnology in plant cultivation and plant ecology. Presently, she is interested in the use of the biomass of plants and other organic fertiliser like biochar in agriculture. 